\title{
PERAN MUSEUM TANI JAWA INDONESIA DALAM PENINGKATAN KINERJA DESA WISATA CANDRAN BANTUL
}

\author{
Oleh \\ Hardi Wahyuno \\ Dosen Sekolah Tinggi Pariwisata AMPTA Yogyakarta \\ e-mail: hardi_wahyono@yahoo.com
}

\begin{abstract}
Since the tourist arrive at location as rural market palce, they will get soon their gaze, as they watch some products. These products include location, price, service, facilities, images, in the dynamic of developement of the local people. The local people is considered to be supplier of the product, as seen in the tourisme point of view. The basic point of view of the tourist is the romantisme and nostalgia is experienced at location and it's relation with the tourist capacity and capability to understand some associations of the products, as products are categorized and branded, under neath they are the controled as well as the tourist understand the meaning of the symbols localy, in the form of cultural goods.

This case raise up some tourismes consideration which this will be studied in the field of comparative rural tourisme, heritage tourisme. The tourists have their own criteria in understanding people 's way of life, developement, condition, in their locality and in the other hands is the people, the way they understand the tourists's need and wants. The relation beetwen local people and tourists attitude is in this contact, communicates the on going matter of tourisme.
\end{abstract}

The attitude of the local people in the tourist village in Candran, they are the creator of their heritage. The heritage has the role for them, because of it's value, in several degree, is coorelatively connected with local history, culture, and nature. This is important to understand the local heritage tourisme.

Diversity of the dynamic rtelation between the village and the city in the tourisme context is significant and it's difference is understood. The village, it's self, in the tourisme context, stengthens the destination of Jogjakarta by producing the tourist village in the setting of rural tourisme, heritage tourisme.

Tourist needs and wants of the rural as product (tangible-intangible) to consume, the local people make some supplies as attraction, acces includes catergorical and brand, where the product : tourist village is typical and specific, valueable, increases the power of attraction , because of it's content, where people respons to challenge in their locality at location. The location (historicval, cultural, natural aspect) can increase tourist's motivation, inisiate the pulled factor, and forme the heritage tourisme, rural tourisme.

The role of the people, in their every day life, is as induvidual or collective local actor, they do, they create heritage for them, they expresse visually, in their attitude toward tourist (performence), as well as their attitude is focused at the rural museum. The people acts as cultural model, otentic, fixing up the proses of consumption (economics). The product to consume is attached with it's association and it's symbolic meaning (cultural).

The Museum Tani Jawa Indonesia in Candran increase the selling value of it's locality and try to fit with the standard expectation toward the global standar as this is the matter of the field in the comparative rural, heritage tourisme. 
Kata Kunci : Museum Tani Jawa Indonesia, Local Actor, Heritage, Rural Tourism, Performance

\section{PENDAHULUAN}

Pariwisata memerlukan penanganan oleh pelaku pariwisata yang berketrampilan, didukung peran kebijakan pemerintah dan sikap masyarakat dengan budaya lokalnya yang spesifik. Pada era pasar bebas, pelaku pariwisata, sebagai bagian dari esensi produk pariwisata, dituntut bisa mengelola ketrampilan yang mengarah pada (a) penguasaan pengetahuan dan (b) pengelolaan ketrampilan (terapan) yang memadai dalam membuat sebuah produk pariwisata, termasuk servicenya (inseparability) memasuki pasar bebas, persaingan bebas yang masuk ke desa. Sekarang, industri pariwisata, industri global, dalam perkembangannya sudah menyentuh wilayah desa. Persentuhan ersebut menghasilkan produk pariwisata teritorial desa : desa wisata, yang terkait dengan keterlibatan peran pemerintah. Peran masyarakat desa terhadap perubahan, dengan memanfaatkan aspek kehidupan, aspek budaya yang masih ada di desa, pengembangan potensi tersebut melibatkan aspek intelektual, material, dan manajerial. Hal itu mendorong tumbuhnya pariwisata di desa untuk merespons/ memenuhi kepentingan ekonomi masyarakat dan kepentingan budaya masyarakat di desa.

Di desa wisata, kepentingan ekonomi dan budaya dapat dipertemukan, masyarakat dapat menegaskan pola perilaku mereka, potensi tersebut dikemas secara spesifik yang melibatkan pemahaman lokal konteks, dapat ditampilkan dalam berbagai produk atraksi wisata budaya yang berlangsung di desa. Dengan adanya desa wisata diharapkan wisatawan memperpanjang length of stay, karena munculnya produk wisata berbeda, berbeda dengan produk yang disajikan dalam mass tourisme. Di dalam desa wisata tersebut di libatkan spesifikasi komponen place (keruangan), actor (pihak lokal spesifik atau wisatawan) dan activity (aktivitas).
Produknya adalah aktivitas keseharian masyarakat pedesaan yang potensial dikemas, dalam kemasan tersebut wisatawan terlibat dengan aktivitas budaya yang ditampilkan. Produk tersebut dalam pariwisata mempunyai spesifikasi dibandingkan dengan produk ekionomi lainnya, spesifikassi nya adalah (1) ia tidak selalu mudah diamati (intangibel) tapi dapat dirasakan, tidak dapat disimpan, dan tidak dapat dipindahkan - terikat dengan lokasi (intransferabel). Pengelolaannya perlu meli-batkan manajemen destinasi yang bertujuan untuk menjamin kualitas destinasi dan kepuasan berwisata (Janianton dan Teguh, 2012). Kualitas destinasi dan kepuasan berwisata satu sama lain terikat ditimbulkan oleh (1) aset pariwisata yang terlindungi dan (2) memunculkan daya saing destinasi melalui tawaran pengalaman pariwisata wisata yang berkualitas.

Pertumbuhan desa wisata di DIY (diperkirakan ada 122 desa wisata), salah satu diantaranya adalah desa wisata Candran, dipimpin oleh Kristya Bintara sekaligus pencetus ide dan pelaksana pembangunan Museum Tani Jawa Indonesia yang berdiri diatas tanah hak miliknya, museum tersebut masuk dalam golongan perusahaan jasa dengan core product : pendidikan, pelatihan dan pelestarian tradisi budaya. Museum tersebut secara fisik dan otoritas hukum adalah milik pribadi Manajemen yang kemudian di 'berikan' sebagai wakaf kepada masysrakat sebagai fasilitas lokasi untuk menunjang keperluan sosial dan pariwisata.

Museum Tani Jawa Indonesia, diharapkan oleh pendirinya menjadi media untuk 'menggerakkan hati generasi muda untuk kemajuan bangsa dan negara dalam bidang pertanian yang kian hari kian 
redup', museum tersebut di Candran telah menjadi lokomotif bagi hidupnya pulled factor produk pariwisata setempat yang berka-tegori budaya (Edward, 2005), yang meng-hidupkan destinasi, yang dikelola dan budaya tersebut dijiwai oleh masysrakat di Candran, masyarakat desa Candran berdiri sebagai 'subyek' bagi budayanya (budaya sendiri) mengelola dan menampakkannya (tangible) sehingga pariwisata berkembang, wisatawanpun datang karena daya tarik (pulled factor) yang ditimbulkannya, wisatawan mendapatkan realisasi pulled factor bagi kunjungannya. Ada 3 paket wisata di Candran (1) Museum tani, pembuatan tempe, biogas,naik perahu naga, bersepeda (2) Museum tani, membatik, bertani, tangkap bebek, (3) Museum tani, bersepeda ke makam raja Imogiri, kerajinan batik, kerajinan keris, pasar tradisional (Herry Mardianto, 2010). Oleh karenanya maka fokus kajian ini adalah sejauh mana pelaku pariwisata/pelaku budaya setempat dalam mendukung pengembangan dan pemusatan keunikan potensi budaya di desa wisata Candran.

\section{PEMBAHASAN}

\section{Manajemen Destinasi Wisata}

Produk pariwisata dikelola untuk mewujudkan suatu integrasi dari komponen produk sehingga bisa diwujudkan dalam bentuk kemasan-kemasan, paket yang ditawarkan. Potensi yang ada dalam suatu wilayah dalam arti alam dan masyarakat budayanya adalah suatu sumber yang harus dipertahankan sekaligus adalah sumber yang dapat diambil sehingga diperoleh potensi untuk pengembangan kemasan diwujudkan di dalam paket misalnya paket wisata. Dalam arti kewilayahan maka hal itu berdampak pada pengembangan wilayah spasial. Karena adanya unsur spesifikasi yang menjadi daya tarik pariwisata. Untuk mengantisipasi perkembangan pariwisata dengan berbagai bentuknya, maka perencanaan kawasan.
Untuk mengakomodasi berbagai kegiatan wisata yang dimaksud. Di sini dapat diperoleh peluang pengembangan pola perilaku pariwisata tertentu yang dikehendaki oleh masyarakat dengan selalu menghindarkan munculnya konflik karena sensitifnya hubungan pariwisata dan lokalitas.

Strategi mengelola pelaku-pelaku, meliputi pelaku dalam bidang kuliner, seni, guide, home stay, masakan, parkir kendaraan. Pelaku-pelaku dengan tugas seperti tersebut sangat dibutuhkan sesuai dengankebutuhan produk, paket yang ada berdasarkan kemasan pertanian, kerajinan, kuliner, kesenian, akomodasi dan permainan yang ada di Candran. Kristya Bintara sebagai owner bertindak sebagai :

1. manajer. Iklim kebrsamaan yang kondusif harus diwujudkannya, memberikan nasehat/masukan melalui menyalurkan informasi tentang pariwisata, memberikan dorongan untuk pelaku bisa berprestasi dalam bidang budaya sesuai tugas masing-masing, mampu melakukan model percontohan tindakan, mendorong supaya keterlibatan dapat dirasakan oleh semua.

2. administrator. Catatan harus dilakukannya dan menyusunnya dalam dokumen mengenai seluruh produk desa wisata, fokus pada hubungan dengan paket, administrasi pelaku, prasarana dan keuangan khususnya.

3. supervisor. Dilakukan supaya ada efesiensi dan efektifitas pelaku dalam jalankan tugasnya, dan melakukan supervisi dalam bentuk pengawasan dan pengendalian .

4. leader. Memberikan petunjuk dan pengawasan,mem berikan motivasi, melalui motivasi untuk meningkatkan kemauan pelaku, warga masysrakat. Harus membuka arus komunikasi dua arah dengan baik antara pelaku, warga dan wisatawan.

5. innovator. Melakukan jalinan hubungan yang harmonis dengan lingkungan dan 
mencari gagasan baru, mengintegrasikan ke dalam setiap kegiatan desa wisata, memberikan contoh tindakan kepada seluruh pelaku dalam desa wisata, mengembangkan model pelatihan untuk pelaku yang tercermin dalam pekerjaan yang dilakukannya secara konstruktif, delegatif, integratif, rasional, obyektif, pragmatik, disiplin, keteladanan, adaptatif dan fleksibel.

6. motivator. Membangun semangat melalui penguasaaan motivasi untuk membangun tugas dan fungsi pelaku melalui pengaturan fisik, pengaturan suasana kerja, disiplin, dorongan, serta memberikan penghargaan secara efektip. Semua pekerjaan tersebut dilakukan dengan menggunakan Museum Tani Jawa Indonesia sebagai sumber inspirasi untuk pelatihan

Dari sudut pandang kepentingan pariwisata, ada peluang dalam hal pengembangan pariwisata di Desa Wisata Candran. Peluang tersebut diraih oleh Manajemen (Kristya Bintara), penduduk asli Desa Wisata Candran, mantan lurah desa KebonAgung, kabupaten Bantul, DIY. Beliau menjadi pemilik usaha pariwisata bergerak secara profesional dalam kategori bidang jasa pendidikan, pelatihan dan pelestarian tradisi budaya ,usaha pariwisata tersebut diwujudkan dalam bentuk fisik museum lokal untuk menunjang perkembangan pariwisata dari segi fisik, dengan nama Museum Tani Jawa Indonesia di Desa Wisata Candran Kabupaten Bantul. Oleh karena itu pengembangannya ditentukan oleh kesatuan sikap dalam manajemen antara pihak pemilik museum. Manajemen dengan masyarakat setempat sebagai pengelola dan sebagai pelaku pariwisata sekaligus penyedia jasa, untuk memenuhi kepuasan wisatawan.

Pariwisata sangat memerlukan manajemen. Manajemen desa dilakukannya, bersama-sama dengan manajemen museum sehingga muncul peluang keterpaduan manajemen desa wisata budaya berbasis museum lokal (manajemen destinasi). Hal ini dilakukan oleh Manajemen secara produktif, selalu melibatkan komunitas. Data sekunder (data pendudukyang terlibat dalam kegiatan wisata di desa candran 2013) menunjukkan, tercatat angka 1539 penduduk usia 0-80 th terlibat dengan kegiatan yang ditimbulkan oleh pariwisata di Desa Wisata Candran. Manajemen berarti proses mencapai sebuah goal dalam suasana kerja sama, proses tersebut meliputi:

1. Fungsi planning yaitu adanya target dicapai dalam ketertataan dan target tersebut dikenal dengan baik oleh kelompok,

2. Fungsi organising yaitu bahwa penguraian ketugasan yang kemudian disusul dengan adanya tugas yang diterima oleh setiap pelaku pariwisata dalam kelompoknya.Tugas tersebut juga menjadi ketugasan bagi masysrakat baik yang terlibat langsung maupun yang tidak,

3. Fungsi leading yaitu: diperlukannya leader/pemimpin yang melakukan kepemimpinan memberikan motivasi dan mempengaruhi kelompok sehingga kompak dalam bekerja sama, pengaruh dan motivasi tersebut berdampak pada efektivitas tugas dilakukan,

4. Controlling yaitu: bahwa diperlukan informasi yang menyeluruh atas semua tugas yang sudah dilakukan sehingga diperoleh tugas-tugas yang belum dan perlu segera dilakukan.

Keempat komponen manajemen tersebut tidak berjalan secara terpisah. Untuk menunjang kesuksesan manajemen memerlukan competency (kemampuan kerja) menekankan pelaku dengan ciri-ciri induvidual menyangkut pola motivasi, skill/ ketrampilan, perilaku yang khas, nilai, atau suatu set pengetahuan yang memungkinkan seseorang menampilkan dengan sukses tugasnya

\section{Keterampilan Pelaku}

Pengertian pelaku adalah warga desa 
Candran yang terlibat dengan kegiatan desa wisata. Mereka mempunyai kekhususan keterampilan dan mampu menyelenggarakan pelayanan sesuai dengan tugas masingmasing sesuai peran. Adapun pelaku yang dimaksud adalah pelaku budaya :warga masyarakat, pelaku inilah yang kami amati.

Pelaku diharapakan mampu memiliki keterampilan dalam mengelola interaksi dengan wisatawan sebagai produk interaktif sehingga menghasilkan output yang berkualitas. Kemampuan pelaku untuk meningkatkan keterampilan, berbasis budaya memperlukan penguasaan pranata sosial, dimana dalam paranata sosial tersebut ada hal-hal yang harus dimiliki dihayati dan dikuasai untuk diaktualisasikan dalam melaksanakan keterampilan sebagai pelaku berbasis budaya. Hal inilah yang menjadi acuan budaya diambil dari kodifikasi perilaku budaya di Candran, sehingga pelaku berketerampilan budaya dapat dimiliki oleh pelaku meliputi keterampilan kepribadian, ketrampilan sosial, ketrampilan profesional, hal ini tidak lepas dari yang disebut dengan ketrampilan pelaku.

Ketrampilan tersebut diaktualisasikan dalaminteraksi dimana pelaku terlibat dengan paket dimana di dalamnya terdapat program wisata dan wisatawan sebagai konsumer, menunjukkan perlunya ketrampilan yang menghandel hubungan antara pelaku dengan wisatawan secara langsung (inseparability). Hal mana menimbulkan tuntutan koordinasi koordinasi yang harus diperhatikan dan ditati sesuai dengan prosedur teknis organisasi pekerjaan, yang menunjukkan adanya unsur kemasan.

Hasil terapannya diharapkan menimbulkan perubahan perilaku wistawan, kepuasan konsumer (eksperiense). Tindakan tersebut sebagai produk intangible, harus dimunculkan, yang memerlukan penguasaan teknis dan pengembangan budaya, dilakukan dengan pelatihan melalui penguasaan media: alat peraga/museum lokal secara lengkap, dimana terdapat berbagai alatalat kehidupan sehari-hari petani maupun perilaku spesifik berlatar belakang budaya lokal. Kualitas ketrampilan pelaku dapat dilihat pada berapa point unjuk kerja yang muncul dari basis interaksi produktif dengan wisatawan, sebagai berikut:

1. Keinginan untuk selalu menampilkan perilaku yang mendekati ideal, standar

2. Meningkatkan dan memelihara citra pelaku/warga desa

3. Keinginan untuk selalu dapat meningkatkan dan memperbaiki kualitas ketrampilan

4. Selalu merasa diri bangga sebagai warga desa dengan budayanya

Pelaku selalu berusaha mencegah terjadinya disorientasi budaya sendiri sebaliknya membangkitkan orientasi budaya bagi wisatawan. Fungsi pelaku adalah meningkatkan martabat dan peran pelaku sebagai agen pariwisata lokal untuk meningkatkan mutu dan citra desa wisata. Ketrampilan-ketrampilan tersebut perlu diintegrasikan dalam kinerja pelaku.

Ketrampilan pelaku juga dituntut oleh bidang seni dan budaya. Hal ini terkait dengan adanya keinginan peningkatan kemampuan dan mutu sumber daya manusia/pelaku didukung oleh kemampuan penguasaan bidang seni dan budaya lokal yang dikuasai, (karena bidang-bidang tersebut diukur diperlakukan sebagai produk pariwisata), dengan tujuan yaitu, tumbuhnya warga desa yang semakin mengerti pariwisata dari sudut pandang budaya lokal dan menjaga martabatnya.

Pelaku dituntut memiliki konsepsi dan memahami prosedur (standar operation prosedur) melakukan tindakan dalam interaksi produktif sesuai dengan obyekobyeknya. Hal mana tidak mudah dilakukan karena adanya bagian obyek yang sifatnya intangibel. Tindakan maupun penjelasannya diarahkan pada wisatawan, menjadi eksplisit, 
terkait dengan kemampuan penguasaan paket wisata. Materi yang intangible perlu dapat di-output-kan untuk wisatawan, karena pemahaman wisatawan terletak pada intangibilitas produk yang dieksplisitkan. Singkatnya ketrampilan pelaku adalah kepemilikan dan penguasaan materi, output yang akan memberikan pemahaman ataupun perubahan perilaku wisatawan untuk lebih memahami budaya desa melalui intangibelitas atau tangibilitass produk sehinngga wistawan puas. Ketrampilan pelaku dalam paket wisata tidaknya dituntut selalu meningkatkan wawasan budaya sekaligus memanfaatkan waktu kunjungan yang efektip sesuai paket.

Pengembangan ketrampilan dilakukan melalui edukasi dan pelatihan yang menunjang peningkatan aspek pengetahuan dan aspek terapan, menggunakan 'alat peraga'/media : museum lokal dimana terdapat berbagai dokumentasi dalam berbagai bentuk ekspresi budaya dan proses budaya. Hal ini menunjang edukasi dan pelatihan pelaku untuk mencapai ketrampilan tertentu. Target menentukan bentuk edukasi dan pelatihan ntuk memenuhi keperluan pariwisata ,khususnya pada aspek terapan dimana antara pelaku dan wisatawan terjadi interaksi hubungan antar aktor/agen secara produktif. Kompetensi pelaku dalam pekerjaannya dapat di bedakan dalam tiga hal:

1. memahami tugas apa yang perlu/urgen dilakukan dalam situasi kritis,

2. cara bagaimana tugas dilakukan (percaya diri, proaktiv, terkontrol, fleksibilitas, efektif bersama wisatawan.

3. tugas dilakukan dalam konteks kelompok (motivasi dipakai, skil interpersonal, persuasi dan mempengaruhi): bersama wisatawan.

Ketiga hal tersebut diperlukan unuk menjalankan, mengoperasionalkan fungsi strategi pelayanan diberlakukan di desa wisata Candran. Strategi sangat diperlukan sehingga kegiatan dapat dilakukan meskipun dalam keadaan menghadapi perbedaan perilaku wisatawan. Strategi dimaksud disusun dengan a plan (rencana tindakan) a ploy, pola perilaku dan posisi pelaku dalam hubungannya dengan konteks kelompok atau perspektif kelompok harus ditaati pelaku sehingga perilaku kerja produktif/ attitude dapat direalisir dan terukur melalui sebuah kontrol standard untuk memenuhi kebutuhan para wisatawan untuk mewujudkan produk ketrampilan intangible pelaku secara induvidual maupun kelompok.

\section{Peran Pelaku Wisata}

Pelaku mempunyai peran penting dalam mengoperasionalkan produk dalam paket wisata di Desa Wisata Candran, pelaku menerapkan pengertian profesi secara benar dari segi pengetahuan maupun dari segi terapan khususnya, karena adanya interaksi wisatawan langsung dengan masyarakat, pelaku dengan wisatawan, sehingga mutu desa wisata ditentukan oleh mutu pelaku. Pelaku harus menemukan cara yang kreatip dalam medekatkan wisatawan dengan obyekobyek yang dimaksud oleh budaya lokal, dikemas dalam paket. Cara yang baik akan membuat wisatawan terkesan mendalam pada paket wisata dan latar belakang paket : budaya lokal, nilai - nilai lokal. Hal mana apresiasi wisatawan sangat dipengaruhi latarbelakang pribadinya, menjadi halhal yang diharapkannya. Wisatawan juga perlu mendapat kebebasan dalam batas tertentu, tetapi dipandu,diatur oleh pelaku dengan interpretasi gelagat yang ada pada perilaku wisatwan yang dihadapi, sehingga wisatawan mendapatkan pemahaman akan nilai budaya lokal dimaksud. Pelaku berperan sebagai pembimbing wisatawan, penasehat, innovator, motivator, pelatih,model, dan sebagai pribadi, pembuka pandangan, pembawa cerita, aktor, emansipator, evaluator yang dilakukanya bersama sama dengan wisatawan dalam bentuk dialog, tindakan singkat. Pelaku bertugas mempertemukan antara informasi obyek, 
makna obyek sesuai dengan kemampuan wisatawan menerima masukan, sehingga wisatawan puas.

\section{Media Museum Lokal}

Media adalah alat komunikasi dan sumber informasi, mengacu pada segala hal yang menghantarkan informasi/makna/ pesan dari sumber kepada penerima. Media adalah segala sesuatu yang dapat dimanfaatkan untuk memperjelas materi atau mencapai tujuan pemahaman tertentu. Museum Tani Jawa Indonesia dikategorikan sebagai museum lokal, media eksposisi, terletak di dalam desa dikelilingi hamparan sawah, sehingga masysrakat setempat selalu dapat menyentuh tangibilitas, intangibilitas produk museum, masyarakat diuntungkan dalam memahami museum lokal secara fisik, arti museum dalam hubungannya dengan budaya sendiri (cultural construction) dan priwisata/kemasan (cultural production), dalam sautu kesatuan makna lingkungan dalam kemasan pariwisata.

\section{Media Eksposisi}

Media adalah alat yang dipakai sebagai saluran untuk menyampaikan materi memperjelas materi yang akan dipahami kepada penerima. Informasi yang dihadirkan dari media, dibalik sejumlah benda-benda fisik terdapat dalam informasi tersebut ketrampilan dan pengetahuan melekat pada obyek-obyeknya disampaikan secara simbolik kepada wisatawan. Peran pelaku adalah menepatkan obyek dan informasi penjelasan obyek yang eksplisit terdapat dalam museum, museum lokal adalah media pembawa pesan diikat oleh budaya lokal, museum adalah teknologi pembawa pesan yang efisen dan efektif. Pada umumnya fungsi museum sebagai media (Warni, 2012) dalam membentuk pesan:

1. mengatasi keterbatasan informasi obyek,

2. melampaui batas keruangan fisik,
3. memungkinkan adanya interaksi lagsung dengan makna obyek,

4. mendorong pelaku dan wisatawan berkeseragaman pengamatan

5. menanamkan konsep yang benar, kongkrit dan relistis,

6. membangkitkan minat ingin tahu,

7. merangsang pemahaman yang komprehensif,

8. memberikan pengalaman yang kongkrit, terpadu dan menyeluruh akan sebuah makna obyek.

Peran pelaku tidak bisa dilepaskan satu dengan lainnya, dan harus membuat pekerjaannya link dan matching dengan tema museum serta fungsinya. Link dan match tersebut berjalan karena pelaku spesifik yaitu petani warga desa.

\section{Media Pembelajaran}

Koleksi dalam museum : bajak, garu, gerobag, cangkul, keranjang, lesung, lumpang, sabit, ani-ani, caping, wajan, cobek, kuali, anglo, tungku, genta, kenthongan, gosrok, genthong, benih padi,alat ritual wiwitan dan merti, memedi sawah, boneka nini thowong, topeng, 260 buah benda dikoleksi dalam museum. Koleksi tersebut bersifat dinamis, selalu ada perubahan: dilakukan oleh pelaku, warga, petani, sehingga meningkatkan kualitas koleksi adalah kegiatan tipikal dilakukan oleh warga sendiri. Benda-benda koleksi tersebut disusun mulai dari 1998 adalah tahun direncanakannya mendirikan museum tani. Koleksi tersebut identik dengan bendabenda alat- alat yang masih digunakan petani sehari-hari karena koleksi tersebut masih banyak terdapat dalam kehidupan keseharian masysrakat; wilayah museum dan museum sendiri secara fisik terbuka untuk masyarakat sehingga kebiasaan warga/petani , upacaraupara, dengan mudah dapat dilaksanakan dalam lokasi di sekitar museum.

Manajemen Museum Tani Jawa 
Indonesia memiliki visi melestarikan tradisi pertanian Indonesia sebagai bagian dari strategi kebudayaan bangsa dan memiliki misi memperjuangkan nilainilai ketahanan pangan bangsa dengan membangun kesejahteraan petani, maka untuk mencapai misi dan visinya tersebut manajemen Museum Tani Jawa Indonesia secara rutin mengadakan kegiatan budaya dan tradisi tani, melalui event-event seperti perlombaan, pentas seni tradisi, dan festival tingkat daerah dan nasional . Urutan kegiatan yang diselenggarakan oleh pelaku/ warga, setiap triwulan meliputi: Bulan januari : lomba tanam padi, bulan Maret : lomba kuliner tradisional desa, bulan Mei: pentas seni tradisi dan budaya, bulan Juli: festival memedi sawah nasional, bulan September: pentas seni tradisi tani, bulan November: expo hasil pangan. Hal ini membuat keberlanjutan destinasi Desa Wisata Candran internal dan eksternal saling berhbungan dan saling mendukung.

\section{Sarana dan Prasarana}

Sarana pokok pariwisata yang tersedia di Desa Wisata Candran adalah obyek wisata dan atraksi wisata yang beridentitas budaya lokal mendukung karakter destinasi. Sedang yang dimaksud dengan prasarana pariwisata adalah semua fasilitas yang memungkinkan agar sarana pariwisata dapat hidup dan berkembang serta dapat memberikan pelayanan pada wisatawan untuk memenuhi kebutuhan mereka yang beraneka ragam (Oka A Yoety, 2003).

\section{Pengembangan Pariwisata}

Pariwisata merupakan salah satu sektor yang membangkitkan multiplayer efek sehingga pariwisata menjadi sangat potensial mampu menggerakkan berbagai sektor dalam masyarakat desa, sehingga pariwisata bisa menjadi alat untuk solusi desa dari persoalan lemahnya pendapatan tetapi sebaliknya potensi budaya menjadi lokomotif dari kemajuan budaya dan solusi lemahnya pendapatan. Perkembangan pariwisata memberikan dampak pada penciptaan tenaga kerja dan peningkatan pendapatan. Pengembangan desa wisata berbasis museum lokal menimbulkan suatu terobosan yang bisa diterapkan pada berbagai wilayah desa sesuai potensinya maupun sesuai dengan keinginan masyarakatnya. Berdasarkan nilai yang strategis di Desa Wisata Candran yaitu nilai budaya lokal justru menjadi potensi unggulan berbasis sejarah lokal khususnya di wilayah Bantul, DIY. Distribusi pariwisata di Jogja dapat diperluas ke dalam wilayah desa wisata. Sehingga justru bisa mendorong pengembangan pariwisata yang lebih luas. Hal ini menguntungkan bagi pariwisata dan fokus kewilayahan (desa wisata). Mass Tourism yang tumbuh dapat menemukan solusinya.

Destinasi adalah bagian dari pariwisata yang menekankan daya tarik dan daya saing pariwisata. Oleh karenanya destinasi bisa membuka diri untuk masuknya aspek diluar pariwisata yang lebih luas, hal mana adalah penting untuk pengembangan baik aspek budaya, lingkungan dan peraturanperaturan yang perlu diubah sehingga bersifat adaptatif terhadap perubahan. Pada dasarnya destinasi adalah zona geografis yang memungkinkan wisatawan bisa tinggal termasuk di dalamnya pengertian pengembangan untuk memberikan titik-titik obyek bagi wisatawan sehingga wisatawan mendapatkan kepuasan wisata. Kepuasan wisata ini tidak lepas dari manajemen mutu dan manajemen baku yang dikaitkan dengan pengembangan daya tarik dan daya saing oleh karenanya produk-produk pariwisata dengan sendirinya menjadi lebih bersifat berkualitas.

\section{Pengembangan Produk Desa Wisata Candran}

Desa wisata adalah bentuk integrasi antara atraksi, akomodasi dan fasilitas pendukung yang tidak lepas dari struktur kehidupan masyarakat yang menyatu dengan 
tata cara dan tradisi yang berlaku (Leli Kusuma Dewi, 2013). Kriteria yang diperlukan oleh desa wisata yaitu:

a. Atraksi wisata, yaitu semua hal yang mencakup nilai budaya, hasil budaya dan perilaku budaya terhadap obyekobyeknya. Atraksi tidak lepas dari unsur akses, amenitas, dan aktivitas bagi wisatawan sehingga dapat dipilih atraksi mana yang menarik dan dapat dipertanggungjawabkan.

b. Jarak tempuh untuk mencapai kawasa tersebut dari pusat-pusat wisata di tempat lain

c. Ukuran desa menyangkut karateristik kependudukan, budaya, alam, arsitektur bangunan rumah dan luas wilayah yang mana terkait dengan carrying capacity

d. Adanya struktur masyarakat desa yang dinilai sangat penting oleh masyarakatnya, sehingga aturan-aturan yang ada perlu dijalankan dan ditaati oleh wisatasan dan tidak langgar oleh masyarakat sendiri

e. Infrastruktur meliputi antara lain, transportasi, fasilitas listrik air bersih, drainase, komunikasi, semua ini perlu diwujudkan secara real.

Karateristik tersebut memungkinkan adanya kriteria desa wisata dapat diwujudkan dalam tipe berhenti sejenak dan tipe tinggal inap. Desa Wisata Candran mempunyai kelebihan karena adanya museum lokal yang digunakan sebagai pendekatan fisik pengembangan desa wisata yang menunjang perkembangan edukasi dan rekreasi dan dapat meningkatkan lebih lanjut pemahaman yang abstrak. Museum tersebut menjadi bagian yang real dari sebuah kegiatan konservasi. Konservasi sangat diperlukan di dalam destinasi. Interaksi dengan masyarakat bersifat setengah langsung karena lemahnya unsur akomodasi di Desa Candran hal ini dapat dilihat dengan adanya paket wisata yang baku yang disediakan oleh manajemen Desa Wisata Candran. Desa Wisata Candran hanya meliputi fokus kehidupan masyarakat sebatas rukun tetangga.

Produk pariwisata dalam sudut pandang desa wisata justru harus terkait dengan peranan masyarakat dan lingkungannya yang dapat dilihat pada basis pemahaman cultural construction, maupun cultural production. Dimana sudut pandang ini masuk di dalamnya adanya unsur wisatawan. Produk pariwisata selalu terikat dengan servis. Adapun produk tersebut dapat melampui batasan wilayah administratif pemerintahan tertentu bahkan produk pariwisata tersebut dapat menghubungkan dua wilayah administrasi yang berbeda. Sedangkan karekter servis yang melekat pada produk adalah, Pertama, ingtangibilitas (tidak bisa diraba), kedua insparabilitas adalah bertemunya provider servis dan customer pada saat proses produksi berlangsung, ketiga, variabilitas yaitu variasinya tergantung pada kualitas pemberi, kapan diberikan, dimana diberikan, keempat, perishabilitas yaitu bahwa kalau servis tidak dipakai servis tersebut akan hangus dengan sendirinya, tidak dapat disimpan. Hal itulah yang memunculkan aspek tangibillitas dan intangibilitas yang melekat pada produk pariwisata dalam visualitas, keruangan, aktivitas dan materi yang melekat pada suatu lokasi. Manajemen Desa wisata Candran mengembangkan gabungan tiga paket wisata,

Paket 1 kunjungan ke museum, ke pabrik tempe, pabrik biogas, naik perahu naga, bersepeda kelilng desa,

Paket 2 kunjungan ke museum, membatik bersama masysrakat, bertani bersama petani, menangkap bebek di sawah,

Paket 3 kunjungan ke museum, bersepeda ke makam Imogiri, mengunjungi kerajinan batik, kerajinan keris, dan ke pasar tradisional. Untuk menunjang paket wisata tersebut,

Manajemen melibatkan berbagai 
kegiatan terdapat di desa lainnya. Oleh karenanya Manajemen melakukan pengelolaan aspek internal dan eksternal: (a) peran menghubungkan antara desa Candran dengan desa lain, hal mana dapat menggerakkan (pemberdayaan partisipasif) sejumlah pelaku terdapat di desa lain,bisa menambah atraksi yang diperlukan oleh wisatawan asing khususnya, sekaligus menggerakkan langkah mencapai standar internasional bagi desa wisata Candran karena mampu mendapatkan kunjungan wisatawan asing, (b) dengan target tersebut maka akan memacu desa wisata lainnya untuk mengembangkan diri, dan mengkerucut jejaring dengan desa wisata lain, memungkinkan diwujudkan dengan adanya promosi bersama antar pelaku desa wisata.

Produk yang baik memerlukan pelaku yang menguasai aspek teori maupaun aspek praktis/terapan yang memadai melalui kompetensi. Produk-produk yang terikat dengan lokasinya tersebut terwujud melalui pembentukan dan peningkatan kemampuan atau ketrampilan atau juga unjuk kerja dari masing-masing pelaku di bidang pariwisata. Kriteria-kriteria pelaku pariwisata menjadi bagian integral dari produk pariwisata yang ditonjolkan dan yang akan ditampilkan (performed), sehingga kriteria pelaku tersebut dapat beradaptasi dengan besarnya tuntutan wisatawan yang selaras dengan harapan wisatawan akan kepuasan yang diwujudkan melalui kontrol produk dan kontrol pelakunya melalui penilaian attitude ,yang dipandang oleh wisatawan dari segi ketrampilan (terapan/performence).

Ketrampilan tersebut dapat dicapai melalui pelaksanaan uji standar ketrampilan , standar ketrampilan tersebut ternyata diperlukan berlaku secara luas dalam suatu komunitas dalam wilayah untuk menunjuk suatu identitas budaya untuk pariwisata, dalam penelitian ini obyeknya adalah Desa Wisata Candran. Pemahaman oleh pelaku tersebut diperlukan oleh wisatawan sehingga wisatawan dapat (1) berhubungan atau berkomunikasi atau berinteraksi langsung dengan pelaku, maupun dengan masyarakat setempat atau penduduk yang terlibat, secara langsung maupun tidak langsung dengan pariwisata. Interaksi tersebut sangat diperlukan oleh wisatawan karena wisatawan sangat memerlukan informasi atas hasil wisatanya,yaitu adanya muatan budaya lokal. Oleh sebab itu, interaksi tersebut harus diperhatikan dengan baik oleh pelaku maupun masyarakat. (b) ketrampilan pelaku dituntut untuk menunjukan suatu bukti yang tangibel menjadi attitude dalam membuat produk barang atau jasa di lapangan, yang mana harus mampu menguasai proses interaksi pariwisata (inseparibility). Interaksi tersebut diperlukan oleh wistawan, karena secara langsung pola dan nilai interaksi tersebut berpengaruh terhadap nilai kepuasan wisatawan.

Kriteria produk dan kontrol produk yang melibatkan pelaku pariwisata, yang berketrampilan sangatlah penting. Pemikiran tentang peningkatan kinerja pelaku inilah yang kemudian mendorong pengamatan pada pentingnya 'alat peraga sosial budaya' untuk pariwisata yang edukatif bagi pelaku pariwisata budaya dalam desa wisata yaitu adanya museum lokal.

\section{Wisatawan Domestik dan Mancanegara}

Wisatawan domestik ada diantaranya pengunjung rutin, pengunjung dari luar daerah dan pengunjung kegiatan kerajinan. Wisatawan mancanegara adalah wisatawan yang ditentukan dari karakteristik status kewarganegaraanya, bahasanya, dan obyekobyek yang menjadi fokus perhatiannya. Hal mana menimbulkan perilaku spesifik karena adanya perbedaan wisatawan asing dan wisatawan domestik. Di Desa Wisata Candran, kunjungan wisatawan asing sebagaian besar adalah berdurasi 7 jam termasuk acara makan siang bersama penduduk dengan menggunakan tradisi makan nasi gurih yang merupakan salah satu 
makanan pokok dalam tradisi yang penting di desa yaitu kenduri. Acara makan siang tersebut biasanya dilakukan dalam wilayah sekitar Museum Tani Jawa Indonesia.

\section{Peran Masyarakat}

Masyarakat menjadi sentral dalam perannya terhadap budayanya dan kawasannya. Budaya yang dimaksud adalah munculnya leadership, hal ini perlu ditekankan justru karena masyarakat adalah pihak yang sangat perlu dilibatkan dalam arti destinasi mapupun dalam arti pariwisata, masyarakat sebagi pelaku dalam berbagai bidang maupun sebagai penjual jasa yang langsung berhadapan dengan wisatawan, hal itu menjadi bagian yang terintegrasi oleh produk pariwisata. Masyarakat menjadi pengelola sekaligus menjadi penyedia fasilitas.

\section{Kinerja Desa Wisata Candran}

\section{Integrasi Kinerja ekonomi dan Non- Ekonomi}

Indikator kinerja ekonomi desa wisata adalah terjadinya tambahan pendapatan pada komu-nitas dan mekanisme pembagian pendapatan dapat lebih bermanfaat pada peningkatan kesejahteraan komunitas desa wisata setempat, terciptanya lapangan pekerjaan dan usaha sektor pariwisata dan keberlanjutan pengembangan komunitas pariwisata desa setempat. Oleh karena Peran Desa Wisata Candran tidak hanya terasa dengan adanya aliran dana langsung sebagai tambahan pendapatan masyarakat, tetapi juga dengan adanya pembangunanpembangunan lain baik fisik maupun nonfisik berupa pelatihan-pelatihan langsung yang mencerdaskan warga baik dalam konteks soft skill (psikologis) maupun hard skill (keahlian) untuk memulai atau mengembangkan usaha lokal sebagai bagian penting dari pengembangan pariwisata secara keseluruhan.
Dalam pengelolaannya, Museum Tani Jawa Indonesia dibantu oleh beberapa orang yang tergabung dalam tim pelaksana untuk menunjang pendekatan fisik pengembangan Desa Wisata Candran, museum ini sudah menjadi anggota Badan Musyawarah MuseumDIY dan menjadi bagian yang penting dari Desa Wisata Candran. Museum Tani Jawa Indonesia di Desa Wisata Candran semakin dikenal karena keberhasilannya memusatkan berbagai atraksi wisata yang berkriteria budaya di Desa Wisata Candran, kriteria budaya tersebut dibuat dan dilakukan oleh pelakunya sendiri yaitu petani setempat.

\section{Atraksi Wisata Budaya}

Desa Wisataa Candran, sampai sekarang, menjadi satu-satunya desa wisata di DIY yang melakukan suatu langkah terobosan melalui produk-produk pariwisata yang bernilai ekonomis dan bernilai budaya yang dimunculkan dalam bentuk atraksi wisata budaya yang menonjolkan pengelolaan potensi lokal meliputi (1) lokasi: desa dan (2) perilaku masyarakatnya: petani setempat. Potensi 'budaya lokal' tersebut difungsikannya sebagai potensi yang dikemas menjadi atraksi wisata. Kedua komponen tersebut didayagunakan dan ditonjolkan sehingga berhasil terintegrasi dan layak diangkat untuk pariwisata melalui realisasi fungsinya didukung oleh adanya bangunan museum : museum lokal.

Museum Tani Jawa Indonesia dapat mengakomodasi unsur-unsur museum dan fungsinya bagi masysrakat Desa Wisata Candran dan masyarakat di sekitarnya dan pariwisata yang dikembangkannya. Museum tersebut menunjukkan fungsi dokumentasi yaitu, a). nilai lokal dalam aspek fisik, visual, keruangan, dan aktivitas masyarakat di dalamnya, dan juga, b). menunjukkan aspek manfaat museum: fungsi edukasi dan fungsi rekreasi. Melalui pariwisata, aspek manfaat museum, yang mencakup manfaat sosial ,budaya/edukasi, pariwisata bagi masyarakat dan wisatawan, dapat diimplementasikan dan diinisiasi untuk memperkuat posisi 
destinasi di Desa Wisata Candran. Dengan menggabungkan kedua aspek tersebut, yaitu aspek fisik dan aspek manfaat, manajemen museum tersebut melakukan suatu rintisan pengembangan produksi pariwisatanya dengan mengembangkan 'performence' budaya (cultural production) salah satu kemasan untuk pariwisata.

\section{Event 'Lomba Tanam dan Tumbuk Padi'}

Pada 12 Mei 2007, museum mengadakan event 'lomba tanam dan tumbuk padi' antar SMA se-DIY untuk memperingati setahun terjadinya gempa bumi di Bantul (24-072006) dengan tema 'Ayo Ramai-ramai Bikin Beras'. Event tersebut merupakan bagian dari atraksi wisata yang berkaitan dengan kemasan pertanian. Di Desa Wisata Candran, kemasan pertanian tersebut didukung oleh : kemasan kerajinan, kemasan kuliner, kemasan kesenian, kemasan akomodasi, dan kemasan permainan.

Event 'Ayo Ramai-ramai Bikin Beras' inimerupakan produk 'performence' pertama pariwisata yang terkait dengan kemasan pertanian, event pariwisata yang terbuka yang disajikan untuk wisatawan. Point of interest nya adalah pada Museum Tani Jawa Indonesia melibatkan interaksi antara aktor 'pemain' dan 'penonton,' yaitu siswa-siswa SMA sebagi peserta lomba dengan pelaku pariwisata dan masyarakat setempat, yang berpusat pada Museum Tani Jawa Indonesia. Format performence tersebut adalah menampilkan gambaran ketertataan atau restrukturisasi semangat kehidupan seharihari petani di desa setelah terjadinya gempa bumi 2006 di Bantul. Di sini tampak adanya hubungan korelasi yang saling mengisi dan saling mengembangkan serta menguatkan antara komponen museum dan pariwisata di Desa Wisata Candran, museum tersebut meningkatan pengetahuan dan ketrampilan masyarakat tentang pariwisata, serta dampak pariwisata mendorong peningkatan ekonomi masyarakat, dan peningkatan potensi budaya.

\section{Media Inspirasi}

Pelaku pariwisata dan masyarakat di sekitar di Desa Wisata Candran melalui Museum Tani Jawa Indonesia sebagai core product, memanfaatkannya meskipun secara non formal tetapi langsung. Secara khusus fungsi museum tersebut berkembang menjadi 'alat peraga' simulasi atau media penting yang menjadi inspirasi budaya dan pariwisata bagi masyarakat. Museum tersebut berfungsi mendukung secara langsung pembelajaran pariwisata sehingga pembelajaran pariwisata oleh masyarakat di Desa Wisata Candran bisa berlangsung, meskipun pembelajaran pariwisata tersebut dilakukan secara otodidak, yaitu antara lain melalui berbagai interaksi secara langsung melalui pelayanan/ service, komunikasi dengan para wisatawan.

\section{Pengembangan Kualitas Tour Guide}

Hadirnya wisatawan mendorong tumbuhnya beragam komunikasi pariwisata. Pemakaian secara langsung (direction use) dari museum tersebut semula dipandu oleh Kristya Bintara sendiri sebagai salah satu pelaku, sebagai pelaku, guide yang memiliki latar belakang dan sumber daya pendukung paling berpengaruh. Pada perkembangan selanjutnya diikuti dengan munculnya pelaku pariwisata lokal yang berketrampilan yang terus meningkatkan diri sampai sekarang, setelah mereka semakin memahami dan semakin mengetahui bagaimana cara menggunakan,memanfaatkan alat peraga yaitu, museum.

Pemahaman tersebut dapat mempengaruhi secara positif meluas pada masyarakat sekitar untuk meningkatkan pemahaman tentang museum dan pariwisata. Interaksi antara pelaku pariwisata dengan museum sebagai alat peraga pariwisata terus berkembang dan menghasilkan pandangan dan tindakan yang produktip dari aspek 
teori maupun terapan bagi pelaku yang memungkinkan mengembangkan pariwisata yang lebih luas yang berlangsung di Desa Wisata Candran. Kualitas pelaku di Desa Wisata Candran merupakan masalah yang memerlukan penanganan multidimensi. Oleh karena itu perlu keterdidikan pelaku dalam pengelolaan pariwisata budaya. Dalam konteks ini, Museum Tani Jawa Indonesia turut menunjang terciptanya pelaku pariwisata yang berkualitas.

\section{Borderzone dan Komunkasi Lokal}

Pariwisata yang berkategori budaya dapat tumbuh dan berkembang di Desa Wisata Candran, karena menguatnya sedikit demi sedikit symbolic space dan bounderynya untuk pariwisata yang didukung oleh pelaku pariwisata dan masyarakat yang sudah berkembang dalam pengertian mereka tentang pariwisata yang berkategori budaya di Desa Wisata Candran, hal ini dapat dilihat pada tiga buah produk paket wisata baku. Pengaruh pariwisata secara ekstensif (efektip dan efisien) tampak pada tumbuhnya beberapa lokasi wisata atau borderzone (zona interaksi pariwisata) yang terpusat pada Museum Tani Jawa Indonesia yang kemudian menyebar di berbagai tempat, desa yang masih tercakup dalam wilayah Desa Wisata Candran dan sekitarnya. Borderzone tersebut menegaskan bahwa aspek-aspek budaya desa dalam kehidupan sehari-hari masyarakat dapat dikelola sebagai potensi dalam kemasan pariwisata dalam berbagai wujud misalnya: kunjungan wisatawam di museum (aspek wisata edukasi budaya desa), kunjungan wisatawan di sungai (aspek wisata alam), kunjungan wisatawan di dalam kelas SD (aspek wisata pendidikan), kunjungan wisatawan di sawah (aspek wisata pertanian) yang terjadi di Desa Wisata Candran, sehingga dapat meragamkan dan memperkaya atraksi wisatanya dengan keragaman kemasan.

Pariwisata ini juga berdampak positif lebih luas yaitu meningkatkan ketertataan wilayah desa untuk pariwisata khususnya. Namun ketertataan tersebut sekaligus juga bisa dipakai oleh penduduk untuk menunjang kehidupan sehari-hari, misalnya: adanya akses berupa jalan (infrastruktur pendukung) yang selalu dirawat karena dampak adanya kesadaran pariwisata. Dalam bidang komunikasi pariwisata, ada peningkatan jumlah penduduk yang tertarik mempelajari berbagai bahasa asing, khususnya Bahasa Inggris, ada juga native speaker dari berbagai bahasa asing misalnya : Belanda, China, Perancis, Denmark, Jerman, Thailand, Malaysia, Yunani, Afganistan, Laos, Palestina, Madagaskar, yang datang sebagai wisatawan. Wisatawan tersebut berkomunikasi dan berinteraksi dengan pelaku dan masyarakat, tetapi masyarakat tetap mempertahankan bahasa Jawa sebagai bahasa daerah dan bahasa Indonesia sebagai bahasa nasional. Kedua bahasa tersebut dipakai sebagai alat komunikasi lokal.

\section{KESIMPULAN}

Sejak wisatwan datang, dalam lokasi desa wisata sebagai rural market place, wisatawn akan memperhatikan aspek produk pariwisata setempat meliputi: lokasi, harga, service, fasilitas. Juga aspek dinamika pergerakan masyarakat setempat (suplier) dari sudut pandang wisatawan berbasis image (romantisme dn nostalgia) dimana image sangat menunjang adanya experience pariwisata meliputi : image, feeling, desire, thought, dan meaning. dan kemampuannya melakukan asosiasi-asosiasi, memahami simbol-simbol atas obyek-obyek dalam batas kemampuan/pengalaman wisata yang ia terapkan di situ. Wisatawan memperhatikan untuk mengetahui produktifitas, hasil tindakan masysrakat, meskipun dengan cara sepintas dalam perlintasannya, lokasi dan latar belakangnya: masyarakat setempat dari aspek sejarah, budaya dan alam, dalam pergerakan aktual yang dilakukan oleh masyarakat tersebut.

Dalam asumsi tersebut wisatawan 
mempu-nyai kriteria (pemikiran dan sikap/ perilaku) dalam menyentuh, menilai interesnya : masyarakat dan pergerakannya, demikian juga pemikiran dan sikap yang dimiliki oleh masyarakat yang dikunjungi, terhadap wisatawan. Hubungan antara ke dua kriteria tersebut mencerminkan hubungan turistik, dengan peran heritage dalam tingkat tertentu di dalamnya. Hubungan antar sikap tersebut bersifat korelatif dan penting dalam memahami pariwisata heritage setempat.

Diversitas hubungan dinamika desakota dalam konteks pariwisata terjadi cukup menonjol, perbedaannya dapat dimengerti. Desa menguatkan destinasi Jogja melalui setting rural tourisme modern (Stephen, 2006). Masing-masing memiliki nilai atraksinya. Kepentingan/ kebutuhan wisatawan (demand) akan desa (rural) sebagai produk pariwisata tangible-intangible melalui kunjungan ke desa (choice) harus diberikan (supplay) karena desa memberikan atraksi wisata yang bernilai spesifik, bernilai lebih, menambah daya tarik muatan yang dalam lokasi wisata memfokus dari sudut sejarah, budaya, dan alam setempat. Bahkan meningkatkan motivasi wisatawan berkunjung secara intensif. Memberikan pengalaman wisata dan kepuasan kunjungan untuk memperkuat setting destinasi yang ekstensif.

Desa, muatannya, memberikan produk tangible-intangible/out put desa wisata Musium Tani Jawa Indonesia, dalam kemasan heritage tourisme (Dallen and Stephen 2003) memberikan kontribusi pada produk/ out put yang signifikan bagi pariwisata heritage. Peranan desa/rural, SDM pariwisata, masyarakat setempat pada umumnya adalah aktor lokal yang menentukan/vital, kreator bagi heritage (gambaran dalam diri mereka yang otentik/ berstandar, sikap ,perilaku aktual yang masih terkait dengan sikap, perilaku terhadap obyek, nilai, dan lingkungan yang terjadi pada masa lalu/the past (dikonservasi dan ditampilkan - tereksekusi dalam performa) di desa setempat yang ditunjuk/dipilih masyarakat untuk menunjang tumbuhnya pariwisata, melalui : (1) model budaya (aktor lokal) berkompetensi dalam melakukan interpretasi budaya, sehingga secara aktual bisa bersikap, berperilaku, personal, proporsional/berstandar, otentik, tingkat otentisitas perilaku/standar perilaku masyarakat pada umumnya dan SDM pariwisata terhadap heritage menunjukkan tingkat posisioning produk heritage, kategori dan brand (3) Musium Tani Jawa Indonesia sebagai museum lokal, lokasinya menjadi bernilai dan posisinya strategis untuk pariwisata setempat mengangkat nilai jual lokasi, sebagai model museum, keruangan dengan fungsi mengkoleksi benda budaya lokal dan memamerkannya untuk memberikan pengetahuan, menghibur dan manajemen bisa menarik keuntungan dalam batas tertentu, menunjang dan mendorong pertumbuhan pariwisata heritage, rural setempat.

Produk heritage dikonsumsi dari sudut produser (acting local) maupun dari sudut konsumer (acting tourist) berlangsung dalam interaksi yang menimbulkan situasi sosial (aktor, aktivitas dan tempat), dimana tempat/lokasi menjadi benda yang produktif, diwujudkan melalui setting situasi sosial pariwisata yang tertata dan terkelola dengan baik, terbukti menjadi produk ekonomis yang bernilai jual dan berbobot.

\section{DAFTAR PUSTAKA}

Dallen J. T. and Stephen W.B. 2003. Heritage Tourism. England: Print and Bound Harlow . Essex.

Edward, M. B. 2005. Culture and Tour. London: University of Chicago Press. Ltd.

Herry Mardianto, 2010. Museum di Yogyakarta, Jendela Peradaban Zaman. Yogyakarta: Dinas 
Kebudayaan Propinsi DIY.

Janianton, D. and Frans Teguh. 2012. Manajemen Destinasi Pariwisata : Sebuah Pengantar Ringkas. Yogyakarta: Kepel Press.

Leli Kusuma Dewi. 2013. Usaha Pemberdayaan Sosial Ekonomi Masyarakat Desa Beraban Dalam Pengelolaan Tanah Lot Secara Berkelanjutan. Analisis Pariwisata. 13/1, $32-44$

Oka A Yoety, 2003. Customer Service Cara Efektif Memuaskan Pelanggan.
Jakarta: Pradnya Paramita

Stephen J. P. J. C. 2006. Tourism a Modern Synthesis. London: Thomson Learning.

Warni, 2012. Pemanfaatan Koleksi Museum Sebagai Media Dan Sumber Pembelajaran IPS Sejarah. Journal of Educational Social Studies. 1/1, $37-41$ 